\title{
Marbeh Hokmah
}




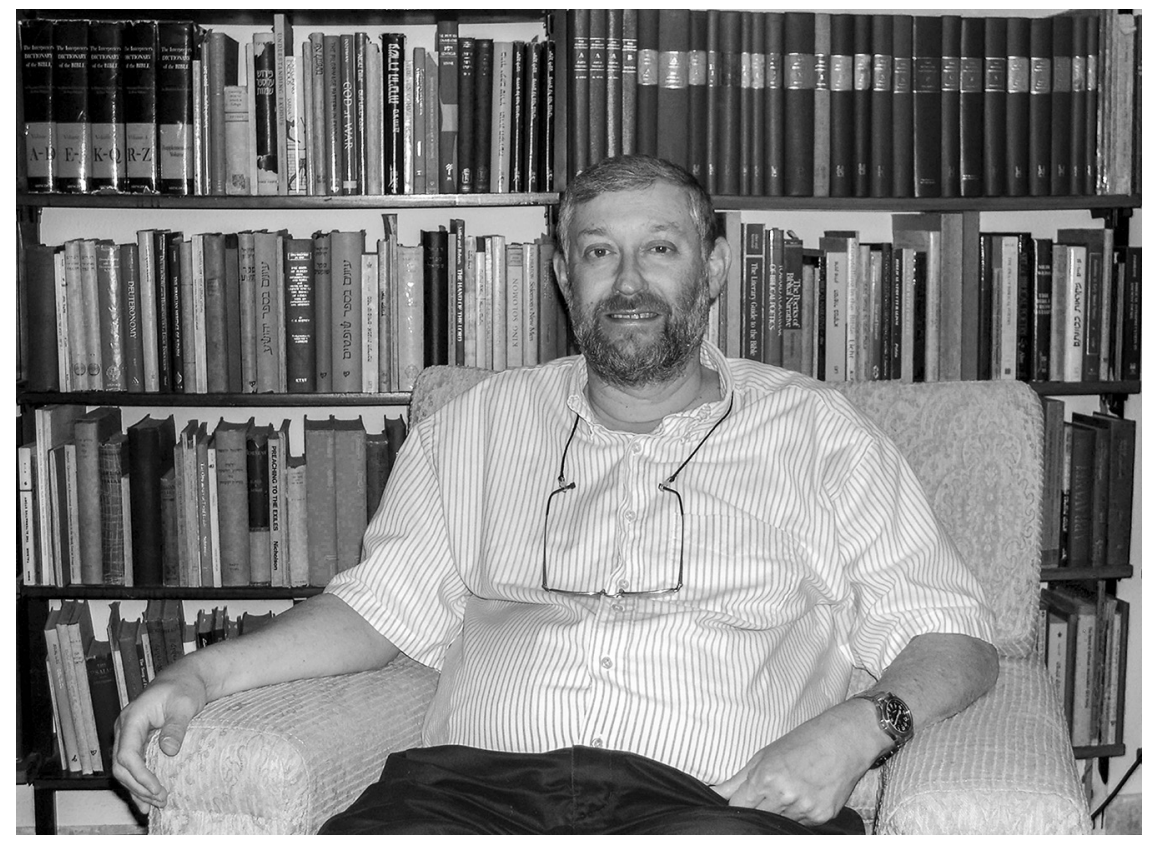

Victor Avigdor Hurowitz 


\section{Marbeh Hokmah}

Studies in the Bible and the Ancient Near East in Loving Memory of

Victor Avigdor Hurowitz

edited by

S. Yona, E. L. Greenstein, M. I. Gruber,

P. Machinist, and S. M. Paul 
Copyright (C) 2015 Eisenbrauns

All rights reserved.

Printed in the United States of America.

www.eisenbrauns.com

\section{Library of Congress Cataloging-in-Publication Data}

Marbeh Hokmah : studies in the Bible and the ancient Near East in loving memory of Victor Avigdor Hurowitz / edited by S. Yona, E. L. Greenstein, M. I. Gruber, P. Machinist, and S. M. Paul. pages $\mathrm{cm}$ Includes bibliographical references and indexes.

ISBN 978-1-57506-415-4 (volume 1, cloth : alk. paper)—ISBN 978-1-57506-416-1 (volume 2, cloth : alk. paper)-ISBN 978-1-57506-333-1 (2-volume set, cloth : alk. paper)

1. Bible-Criticism, interpretation, etc. 2. Semitic philology. 3. AssyroBabylonian literature-History and criticism. I. Hurowitz, Victor, honoree.

II. Yona, Shamir, editor.

BS511.3.M3266 2015

$221.6-\mathrm{dc} 23$

The paper used in this publication meets the minimum requirements of the American National Standard for Information Sciences-Permanence of Paper for Printed Library Materials. ANSI Z39.48-1984.@TM 